\title{
PRASA BRYTYJSKA W POLITYCE INFORMACYJNO-PROPAGANDOWEJ II RP
}

Natalia Micygała

http://orcid.org/0000-0001-9388-9037

Uniwersytet Jagielloński w Krakowie

\section{ABSTRACT \\ BRITISH PRESS IN THE INFORMATION AND PROPAGANDA POLICIES OF POLAND IN THE INTERWAR PERIOD}

In the interwar period, the British press, both elite and mass, expressed little interest in the foreign affairs of Great Britain. Poland as a state lying in Central and Eastern Europe could not expect any special concern from the British press. However rarely, information about Poland did appear in British newspapers. The author tried to show what it looked like from the technical point of view. The problem was discussed primarily from the point of view of the way British journalists were informed about Poland, the relations between the journalists and representatives of Polish diplomacy, as well as Polish attempts to affect the way Poland was showed in the dailies. The analysis was carried out from both a general as well as a more specific perspective.

Key words: British press, information and propaganda policy, interwar period, Polish Embassy in London.

Słowa kluczowe: prasa brytyjska, polityka informacyjno-propagandowa, okres międzywojenny, Ambasada RP w Londynie.

Charakter i znaczenie prasy brytyjskiej, którą znamy z pierwszej połowy XX wie$\mathrm{ku}$, były owocem szerokich zmian, jakie zachodziły na ogólnoeuropejskim rynku informacji w XIX i pierwszych latach XX wieku¹. Cztery grupy zjawisk miały największy, trudny do przecenienia wpływ na rewolucję rynku prasowego: kulturowe (rozwój edukacji, zwiększenie potrzeb kulturalnych), polityczne (włączenie w życie polityczne coraz szerszych mas, powstanie nowoczesnych partii politycznych), społeczne (przekształcenie układu sił społecznych) oraz technologiczne (rozwój

1 A. Słomkowska, Krótki zarys historii prasy brytyjskiej, Warszawa 1978, s. 30-31. 
telegrafu i kolei) ${ }^{2}$. Dzięki tym wielokierunkowym zmianom pojawił się grunt do zakładania wielu nowych, a przede wszystkim tanich i powszechnych gazet. Pojawiła się szeroka grupa czytelników, którzy oczekiwali przystępnego przekazu. Stąd już było blisko do powstania tak zwanej prasy masowej skierowanej do prostego, masowego odbiorcy ${ }^{3}$. Prasy przeznaczonej do przeglądania, a nie czytania ${ }^{4}$. Idealnie dostosowanej do zmęczonych pracowników fabryk wracających do domu po ciężkim dniu pracy, niepotrafiących skupić swojej uwagi na czymkolwiek wymagającym wysiłku umysłowego ${ }^{5}$. Od tej pory wyroki Brytyjczyków zaczęły coraz częściej zapadać na podstawie bezrefleksyjnie czytanych nagłówków 6 .

Równolegle $\mathrm{z}$ upowszechnianiem i upraszczaniem prasy pojawiło się elitarne grono osób przejmujących lub zakładających coraz to nowe czasopisma. Przebić do niego mogli się jedynie ci, którzy posiadali wystarczający kapitał finansowy, aby sprostać wymaganiom rynku wdrażającego kolejne nowinki technologiczne ${ }^{7}$. Nazywano ich magnatami prasowymi, co miało obrazować nie tylko pozycję finansową, ale także ogromne wpływy na Fleet Street będącej sercem i mózgiem brytyjskiego rynku informacji. Pierwszym magnatem prasowym był lord Northcliffe, po nim pojawili się jeszcze lord Beaverbrook oraz lord Rothemere ${ }^{8}$.

$\mathrm{W}$ pierwszej połowie XX wieku prasa znajdowała się w całkowicie nowym miejscu. Z jednej strony przeżywała kryzys, który dotyczył spadku jakości przekazywanych informacji, przede wszystkim przez prasę masową. Wysoki standard zachowały tylko gazety elitarne, które w efekcie nie sprostały konkurencji i docierały do wąskiego grona czytelników. W gronie tym wymienić należy przede wszystkim prorządowy „The Times”, liberalny „Manchester Guardian” oraz konserwatywny „Daily Telegraph" skalę czytać gazety ${ }^{10}$. Cel ten został osiągnięty dużym kosztem, przede wszystkim finansowym, związanym z prowadzeniem przez największe gazety tak zwanej wojny o nakład polegającej na przekupywaniu klientów, a dokładnie zachęcaniu ich do

2 A. Paczkowski, Czwarta władza. Prasa dawniej i dziś, Warszawa 1973, s. 8-9.

3 D. Griffiths, A Century of Journalism, 1900-2000, Oxford 2012, s. 4; K. Williams, Read All about It!: A History of the British Newspaper, London 2009, s. 126.

4 K. Williams, op. cit., s. 129.

5 G. Boyce, J. Curran, Newspaper History from the Seventeenth Century to the Present, London 1978, s. 40.

${ }^{6}$ Ibidem, s. $37-38$.

7 A. Słomkowska, op. cit., s. 57.

Ibidem, s. 53; D. Griffiths, op. cit., s. 4; K. Williams, op. cit., s. 126.

H. Kuta, L. Meissner, Prasa za granica. Sylwetki 147 wybranych dzienników i czasopism z 39 krajów oraz krótkie charakterystyki 14 agencji prasowych, Kraków 1972, s. 320; A Journalism Reader, eds. M. Bromley, T. O'Malley, London 1997, s. 102; M. Walker, Power of the Press: The World's Great newspapers, London 1995 s. 43-44; I. McDonald, The History of the Times. Vol. 5: Struggles in War and Peace, 1939-1966, London 1984, s. 12.

10 W przededniu wojny $69 \%$ Brytyjczyków czytało regularnie dzienniki, a $82 \%$ gazety niedzielne. Warto więc spojrzeć na wojnę o nakład jak na zjawisko, dzięki któremu Brytyjczycy nauczyli się czytać gazety. A. Słomkowska, op. cit., s. 70-71; G. Boyce, J. Curran, op. cit., s. 131. 
prenumeraty różnego rodzaju dodatkami do gazet, które przy okazji zaprowadziły niektóre koncerny prasowe na skraj bankructwa ${ }^{11}$.

\section{POLSKIE INSTYTUCJE ODPOWIEDZIALNE ZA KONTAKTY Z PRASA BRYTYJSKA}

Jednym z czołowych zadań polskiej służby dyplomatycznej w okresie dwudziestolecia międzywojennego było prowadzenie akcji informacyjno-promocyjnej, nazywanej w tamtym okresie informacyjno-propagandową, przy użyciu chociażby środków masowego przekazu. Był to okres, w którym coraz większą popularność zdobywało radio, choć nie zdążyło jeszcze zdetronizować prasy, której nakład wzrastał między innymi w związku z wojną o nakład.

W ramach polskiej służby dyplomatycznej funkcjonowały specjalne komórki i jednostki odpowiedzialne za akcje promocyjne i kontakty z prasą. Część z tych zadań należała niezmiennie do działających na Wyspach Brytyjskich polskich placówek dyplomatycznych - przede wszystkim Poselstwa, a od 1929 roku Ambasady RP w Londynie. Aktywność ta była dopełniana przez pracę Wydziału Prasowego P VI stworzonego w ramach Ministerstwa Spraw Zagranicznych. Wydział powstał jeszcze w okresie premierostwa Ignacego Paderewskiego, również wtedy określono podstawowe zadania jednostki, do których należało między innymi udzielanie informacji o Polsce przedstawicielom i korespondentom zagranicznym, opracowywanie sprawozdań z zagranicznych gazet, kontrola serwisu Polskiej Agencji Telegraficznej (PAT) w zakresie spraw międzynarodowych i zagranicznych, przekazywanie agencjom prasowym przeglądów prasowych, komunikatów politycznych i wiadomości, a od 1921 roku rozwijanie za pośrednictwem agend dyplomatycznych akcji informacyjno-propagandowej w krajach obcych ${ }^{12}$. W 1927 roku dokonano reorganizacji Wydziału P VI i podziału na pięć referatów: wschodni, zachodni, prasy polskiej, informacyjny (przekazywanie informacji, np. przebywającym w Polsce korespondentom zagranicznym) oraz propagandowy ${ }^{13}$.

Obok Wydziału P VI kluczową rolę w organizacji akcji informacyjno-propagandowej odrywała Ambasada RP w Londynie. W jej strukturach za kontakty z prasą odpowiedzialne były przede wszystkim osoby pełniące trzy funkcje: posła, a od 1929 roku ambasadora, którego zadaniem było utrzymywanie relacji z najważniejszymi osobistościami świata prasy; sekretarza (przez całe lata 30. był to Jan Tomaszewski) zajmującego się przede wszystkim sporządzaniem raportów prasowych oraz prowadzeniem korespondencji z dziennikarzami; oraz referenta prasowego (od

11 H. Richards, The Bloody Circus: The Daily Herald and the Left, London 1997, s. 149.

12 W obliczu wojny. Z prasy polskiej 1939 roku, wybór i oprac. red. miesięcznika „Znak”, Kraków 1984, s. 128.

13 Ibidem, s. 426-428; K. Szczepanik, Dyplomacja Polski 1918-2000. Struktury organizacyjne, Warszawa 2000, s. 31-35; 53-55. 
1919 r. był nim Franciszek Bauer-Czarnomski), który dokonywał przeglądów prasowych, oraz podobnie jak sekretarz był odpowiedzialny za utrzymywanie kontaktów $\mathrm{z}$ dziennikarzami z Fleet Street ${ }^{14}$.

Podstawowym, bo wykonywanym z największą regularnością, zadaniem było sporządzanie raportów prasowych, zarówno tygodniowych, jak i miesięcznych oraz rocznych. Po reorganizacji w 1927 roku Wydziału P VI (który m.in. zaczął wydawać biuletyny przedrukowujące zagraniczne publikacje o Polsce) ambasada miała przesyłać do centrali jedynie informacje o najgłośniejszych spośród nich ${ }^{15}$. Z zadania bez wątpienia wywiązywano się, przynajmniej częściowo, czego świadectwem są zachowane materiały archiwalne. Największym uchybieniem miała być nieterminowość, co uniemożliwiało ewentualną reakcję na krytyczne względem Polski artykuły ${ }^{16}$.

Londyńska ambasada pełniła także bardziej aktywną rolę polegającą na prowadzeniu w środowisku dziennikarskim pozytywnej promocji, inspirowaniu redakcji i dziennikarzy do podjęcia nowych tematów mogących zainteresować Brytyjczyków, a także na reagowaniu na wszelkie nieprzychylne artykuły prasowe na temat Polski ${ }^{17}$. Najtrudniej było efektywnie protestować przeciwko treściom w już wydrukowanych artykułach. Jedyną możliwością było wystosowywanie oficjalnych not protestacyjnych z prośbą o sprostowanie kłamliwych i niesłusznych informacji. Niestety tego typu działania były zazwyczaj bezskuteczne, ponieważ gazety bardzo niechętnie przedrukowywały jakiekolwiek sprostowania, „inne zaś pisma sprostowania nie przyjmowały do druku dla względów jakiejś zawodowej solidarności”'18.

Obok not protestacyjnych popularną formą były tak zwane listy do redakcji będące w Wielkiej Brytanii dość częstą formą interakcji między redakcją a czytelnikami, którzy chcieli ustosunkować się do zamieszczanych w prasie artykułów. Drukowano je rzecz jasna wybiórczo. Ambasada również wykorzystywała tę możliwość. Tradycyjnie była to sfera zadań należąca do Bauer-Czarnomskiego, jednak w najbardziej palących sprawach listy do redakcji wychodziły spod pióra kierowników londyńskiej placówki - Konstantego Skirmunta oraz Edwarda Raczyńskiego. Kolejną metodą było przesyłanie agencjom prasowym, przede wszystkim Reutersowi, mającemu największe wpływy na rynku prasowym ${ }^{19}$, komunikatów, które tą pośrednią drogą trafiały ostatecznie na biurka redaktorów. Stosowano także metody nieoficjalne, które często miały największą potencjalną skuteczność. Dyplomaci mający realne wpływy

${ }_{14}$ Archiwum Akt Nowych w Warszawie (dalej: AAN), Ambasada RP w Londynie (dalej: ARPL), 729, korespondencja Jana Tomaszewskiego z Januszem Kruszyńskim, radcą MSZ w wydziale prasowym z dn. 26 V 1937 r., k. 71; AAN, ARPL, 941, Raport polityczno-prasowy Konstantego Skirmunta ze stycznia 1933 r., k. 116.

15 AAN, ARPL, 941, Pismo nr 463 z 15 III 1926 r., k. 3-4.

16 AAN, ARPL, 7794, Notatka z wydziału zachodniego MSZ do Naczelnika Wydziału Prasowego MSZ z 12 IV 1935 r., k. 19.

17 W AAN, ARPL znajduje się liczna korespondencja, przede wszystkim sekretarza ambasady Jana Tomaszewskiego, z osobami powiązanymi z prasą brytyjską, przykładowo v., 729, List Jana Tomaszewskiego do Daltona MacDonalda z 17 III 1939 r., k. 19.

18 K. Skirmunt, Moje wspomnienia 1866-1945, Rzeszów 1997, s. 173.

19 J. Silberstein-Loeb, The International Distribution of the News: The Associated Press, Press Association and Reuters, 1848-1947, Cambridge 2014, s. 150-151. 
w środowisku brytyjskim próbowali inspirować zaufanych dziennikarzy do podejmowania reakcji przeciwko niesprawiedliwym wobec Polski informacjom prasowym ${ }^{20}$.

Kazimierz Skirmunt w swoich wspomnieniach z lat 20. stworzył ciekawą charakterystykę brytyjskiego rynku prasowego. Dowodził w nich, że nikt w Londynie nie podejmował się próby przekupstwa dla uzyskania przychylnych artykułów, niezależnie od tego, czy miałaby mieć formę subsydiów czy jednorazowych zapłat za przychylne treści. Działać trzeba było delikatnie, z gracją, a było to możliwe, gdyż dziennikarze brytyjscy bardzo chętnie wchodzili w różnego rodzaju relacje towarzyskie, co stwarzało szansę na podjęcie dyskusji politycznych i przekonanie do słuszności swoich racji ${ }^{21}$.

Działania prowadzono wszechstronnie, $w$ jakim jednak stopniu przynosiły one wymierne efekty? W materiałach archiwalnych zachowało się sporo informacji na temat podejmowanych przez pracowników londyńskiej ambasady licznych interwencji w związku z koniecznością sprostowywania informacji prasowych. Mniej niestety wiemy o generalnej skuteczności tych działan, choć indywidualne sukcesy osiągano. Na przykład w 1935 roku redaktor polityczny „Manchester Guardian” Frederick Voigt zadeklarował, że w przyszłości będzie się zwracał do strony polskiej o przedstawienie stanowiska, jeśli będzie podejmował decyzję w przedmiocie publikacji kontrowersyjnych materiałów na temat Polski. Wydaje się, że deklaracja była przez niego przestrzegana, po 1935 roku bowiem nie ma śladów zgrzytów na linii Voigt-Ambasada, a w wewnętrznych sprawozdaniach opisywano go jako jednego z bardziej przychylnych Polsce dziennikarzy ${ }^{22}$.

Oceniając całokształt polityki informacyjno-prasowej, a nie indywidualne sprawy i problemy, trudno jednak mówić o spektakularnych sukcesach. Częściowo wynikało to z faktu, że po 1926 roku władze II RP skupiły się na propagandzie wewnętrznej, na czym w pewnej mierze ucierpiała też propaganda zewnętrzna. Polska dyplomacja miała godny uwagi wzór do naśladowania - Czechów mających przez większość międzywojnia te same bariery do przeskoczenia w relacjach z Wielką Brytanią ogromne trudności w zainteresowaniu regionem Europy Środkowo-Wschodniej ${ }^{23}$. Sytuację Warszawy komplikowały, zwłaszcza w oczach prasy liberalnej, polityka mniejszościowa (przede wszystkim skierowana do największych mniejszości - ukraińskiej i żydowskiej), a także przez większość dwudziestolecia międzywojennego relacje z sąsiadami: Związkiem Sowieckim oraz Niemcami ${ }^{24}$. Niemal symbolem problemu były wydarzenia z 1931 roku nazywane pacyfikacją Małopolski Wschodniej,

20 AAN, ARPL, 941, Raport polityczno-prasowy Konstantego Skirmunta ze stycznia 1933 r., k. 121.

${ }_{21}$ Zob. K. Skirmunt, op. cit., s. 175.

22 Instytut Polski i Muzeum im. gen. Sikorskiego w Londynie (dalej: IPMS), ARPL, A.12.327/3, Pismo Jana Tomaszewskiego do Wydziału Prasowego MSZ, k. 19.

23 W obliczu wojny..., s. 429.

24 Powstała monografia dotycząca ukraińskiej propagandy na obszarze Europy Zachodniej, v. Lobbing dla Ukrainy w Europie międzywojennej. Ukraińskie Biuro Prasowe w Londynie oraz jego konkurenci polityczni (do roku 1932), Kraków 2010; AAN, ARPL, Pismo sekretarza konsulatu generalnego w Manchesterze Jana Woyczyńskiego do Ambasady RP w Londynie z 26 XI 1937 r., k. 115. 
które przez kilka tygodni nie schodziły ze stron najważniejszych brytyjskich gazet i mocno podkopały jakiekolwiek sympatie Brytyjczyków do kraju nad Wisłą.

Dodatkowym utrapieniem było permanentne prowadzenie antypolskiej propagandy przez czynniki związane z państwem niemieckim, państwem sowieckim czy narodem ukraińskim. W latach 20. XX wieku MSZ narzekało najbardziej na działania niemieckie. Kulminacyjnymi momentami miały być: rok 1932 (działania niemieckie) oraz rok 1937, gdy regularną antypolską propagandę próbowano skojarzyć ze Związkiem Sowieckim. W kontekście Holandii Janusz Sobczak pisał, że część tamtejszego środowiska dziennikarskiego wychodziła z założenia, że Niemcy przejęli od Polskiej Agencji Telegraficznej funkcję przekazywania informacji na temat Polski ${ }^{25}$. Przewaga Niemiec wynikała z dwóch czynników. Pierwszym z nich były niezmienne sympatie proniemieckie widoczne zwłaszcza na łamach prasy popularnej, drugim natomiast (bez wątpienia determinującym także czynnik pierwszy) wysokie nakłady finansowe Republiki Weimarskiej, a później III Rzeszy na akcje propagandowe. Pieniądze były czynnikiem istotnym, choć pośrednim, umożliwiały na przykład utrzymywanie licznego personelu odpowiedzialnego za kontakty z pra$\mathrm{są}^{26}$. Nie były natomiast angielskim zwyczajem próby przekupstwa w celu uzyskania przychylnego stanowiska gazet.

Najważniejszej roli nie odgrywały ani pieniądze, ani noty protestacyjne, a działania pośrednie, które trzeba było przeprowadzać delikatnie, z gracją, co mogło się wydawać łatwe, gdyż dziennikarze brytyjscy bardzo chętnie wchodzili w różnego rodzaju relacje towarzyskie, z których jedną z popularniejszych form było wspólne spożywanie śniadań, podczas których dyskutowano o sprawach politycznych różnej wagi. Dzięki bezpośrednim kontaktom i dyskusjom łatwiej było przekonać nieprzekonanych do słuszności polskich racji. Konstanty Skirmunt pisał w swoich wspomnieniach, że dzięki tego typu zabiegom udało mu się nawiązać poprawne relacje z kilkoma dziennikarzami angielskimi, jak choćby z Henrym Wickhamem Steedem (,The Times”) oraz Jakubem Garvinem („Observer”) ${ }^{27}$. Podobne wnioski można wyciągnąć ze wspomnień Edwarda Raczyńskiego, który również starał się utrzymywać relacje ze światkiem dziennikarskim ${ }^{28}$.

\section{MECHANIZMY POZYSKIWANIA INFORMACJI O POLSCE}

Brytyjskie gazety zdobywały informacje na temat Polski (oraz wszystkich innych państw europejskich i nie tylko) z kilku źródeł. Podstawowym, zwłaszcza dla gigantów rynku prasowego oraz dla agencji prasowych (przede wszystkim Reuters

25 J. Sobczak, Propaganda zagraniczna Niemiec Weimarskich wobec Polski, Poznań 1973, s. 71.

26 T. Pudłocki, Ambasadorzy idei. Wkład intelektualistów w promowanie pozytywnego wizerunku Polski w Wielkiej Brytanii w latach 1918-1939, Kraków 2015, s. 42-45.

27 K. Skirmunt, op. cit., s. 170.

28 E. Raczyński, op. cit. 
i Associated Press) dysponujących wystarczającym budżetem, było zatrudnianie stałych korespondentów. Oprócz nich korespondentów w Polsce opłacało kilka mniejszych tytułów prasowych, wśród których dominowały gazety żydowskie, co nie powinno dziwić 29 .

Znaczna część dziennikarzy pracujących z Warszawy była nieporównywalnie bardziej związana z Polską niż z Wielką Brytanią. Posiadali nazwiska i obywatelstwo polskie, mieszkali całe życie w Polsce, a wyróżniało ich jedynie to, że utrzymywali się, lub jedynie dorabiali, dzięki pracy dla zagranicznych koncernów prasowych. Nie mówimy tutaj o dużych liczbach. Do końca lat 20. XX wieku w Warszawie przebywało zaledwie kilku stałych korespondentów powiązanych $\mathrm{z}$ brytyjskim rynkiem prasowym, w tym jeden Anglik - pracujący dla „The Timesa” Barker (o nieznanym imieniu), który zresztą nie pełnił tej funkcji zbyt długo ${ }^{30}$.

Polska dyplomacja czyniła starania zmierzające do zwiększenia ich liczby. Wynikało to przede wszystkim z przeświadczenia, że ograniczenia w liczbie prawdziwych korespondentów zagranicznych oraz kontynuacja przedwojennej praktyki polegającej na przekazywaniu informacji o ziemiach polskich przez dziennikarzy stacjonujących w Wiedniu i Berlinie przynosiły konkretne negatywne skutki - rosnące przekonanie społeczeństwa brytyjskiego o marginalnej roli II Rzeczpospolitej i poczucie jej przedmiotowości, a nie podmiotowości, w polityce międzynarodowej ${ }^{31}$. W pierwszej połowie lat 30. istotnymi przeciwnikami w osiągnięciu celu zwiększenia liczby korespondentów zagranicznych były kryzys gospodarczy oraz tradycyjnie niewielkie zainteresowanie Brytyjczyków polityką zagraniczną, a Europą Środkowo-Wschodnią w szczególności ${ }^{32}$. Kryzys gospodarczy spowodował, że również koncerny prasowe musiały szukać oszczędności w swoich budżetach, co najłatwiej było osiągnąć między innymi dzięki ograniczeniu liczby zatrudnianych korespondentów, zwłaszcza na mniej priorytetowych obszarach. Ministerstwo spraw zagranicznych próbowało ominąć ten problem przez branie - bezpośrednio na siebie lub pośrednio przez takie instytucje jak Bank Polski - części kosztów utrzymania zagranicznych dziennikarzy. Przekazywanie dodatków finansowych miało powodować, że praca w Polsce miałaby się stać nie tyle intratna, ile po prostu opłacalna ${ }^{33}$. Na podstawie zachowanych dokumentów nie można jednoznacznie ustalić, czy działania podejmowane przez stronę polską były efektywne. Wiadomo natomiast, że już w 1935 roku przebywało

29 Mowa o takich gazetach jak „Jewish Chronicle” czy „Jewish Post”.

301930 r. był kryzysowy pod względem liczby korespondentów. Miało to wynikać z niewielkiego zainteresowania polityką zagraniczną oraz z kryzysu gospodarczego, który spowodował odwołanie korespondentów przez największe gazety, np. „The Times”, „Daily Express”, „Daily Mail”, v. AAN, ARPL, 969, list Wiktora Drymera do Ambasady z 4 III 1930 r., k. 2-3; AAN, ARPL, 941, Raport polityczno-prasowy Konstantego Skirmunta ze stycznia 1933 r., k. 120.

31 Polskie dokumenty dyplomatyczne 1931, red. M. Woło s, Warszawa 2008, s. 280-281.

32 AAN, ARPL, 696, Pismo ambasadora Skirmunta do Wydziału Prasowego MSZ z 25 III 1930 r., k. 3; AAN, ARPL, 7934, Pismo ambasadora Skirmunta do Wydziału Prasowego MSZ z 23 II 1933 r., k. $117-118$.

33 Metodę tę zastosowano jedynie względem osób niemieszkających na stałe nad Wisłą, znanych z przyjaznego ustosunkowania do Polski, v. AAN, ARPL, 7934, Pismo do prezesa Banku Polskiego w Warszawie, dokładna data nieznana, [b.p.]. 
w Polsce dwunastu korespondentów gazet brytyjskich, w tym najprawdopodobniej czterech rodowitych Anglików ${ }^{34}$.

Kolejnym charakterystycznym zjawiskiem związanym z ograniczaniem wydatków było zatrudnianie jednej osoby przez kilka gazet, niekoniecznie należących do tego samego koncernu prasowego. Na przykład niejaki Joel Cang pracował w 1936 roku dla „Manchester Guardian” i „News Chronicle”, a Gilbert Redfern dla „The Economist”, „The Times” i „Daily Telegraph”35. Cangowi musiało niewielką trudność sprawiać pisanie dla gazet dość podobnych pod kątem światopoglądu. W innym przypadku konieczne było dostosowywanie tematyki i wydźwięku artykułów do charakteru gazet, co zresztą czyniono ${ }^{36}$. Była to świetna wymówka dla dziennikarzy, którzy - atakowani przez polskich dyplomatów za wszelkie nieprzychylne treści mogli tłumaczyć się koniecznością dostosowania tematyki i języka do potrzeb wydawcy ${ }^{37}$. Nie zmienia to faktu, że zdarzali się również korespondenci, którzy szczerze nie darzyli Polski i Polaków sympatią, czego nawet nie starali się ukryć. Osoby nad wyraz uciążliwe strona polska starała się usuwać z Warszawy, co czasami przynosiło rezultaty, zwłaszcza jeśli było przeprowadzone dyskretnie ${ }^{38}$.

Ważną rolę w systemie przekazywania informacji odgrywali także korespondenci nadzwyczajni, którzy byli zatrudniani tymczasowo, w celu podjęcia jednego konkretnego zagadnienia ${ }^{39}$. Zwykle byli to znani publicyści i pisarze. W przeciwieństwie do korespondentów stałych mieli kontakt zarówno z pracownikami londyńskiej ambasady, jak i warszawskiej centrali, przede wszystkim Wydziału P VI. Ambasada była odpowiedzialna za przygotowanie wyjazdu do Polski, tak aby komfort był jak największy, a ceny jak najniższe. Działania podejmowano wszechstronnie: od załatwiania darmowych karnetów na podróże Polskimi Kolejami Państwowymi do podejmowania interwencji w kwestii zbyt wygórowanych cen $\mathrm{w}$ renomowanych hotelach cieszących się zainteresowaniem wśród zagranicznych gości.

Po przyjeździe do Polski nadzwyczajni korespondenci zabiegali o wyjątkowe materiały, do których należały wywiady z najważniejszymi polskimi politykami. Najbardziej zabiegano o możliwość rozmowy z Józefem Piłsudskim, co było jednak nieosiągalne - Marszałek bardzo rzadko udzielał jakichkolwiek wywiadów. Zaraz po Piłsudskim największym zainteresowaniem prasy cieszył się Edward Rydz-Śmigły oraz prezydent Mościcki. Również oni nie byli stale dostępni dla zagranicznych korespondentów. Zdarzało się, że czasu na wywiad nie znajdowali przywódcy sanacji, w przeciwieństwie do przedstawicieli opozycji, którzy nad wyraz chętnie spotykali

${ }^{34}$ Archiwum Akt Nowych w Warszawie (dalej: AAN), zespół Ministerstwo Spraw Zagranicznych, 1918-1939 (dalej: MSZ), 7788, k. 135-136.

${ }^{35}$ Ibidem.

36 IPMS, A.12.327/4, k. 17; AAN, ARPL, 729, list Jana Tomaszewskiego do Janusza Kruszyńskiego z 26 IV 1937 r., k. 60.

37 AAN, ARPL, 729, List Janusza Kruszyńskiego do Jana Tomaszewskiego z 11 V 1937 r., k. 62.

38 Brytyjskie środowisko dziennikarskie było przewrażliwione na punkcie zachowania niezależności od czynników zewnętrznych, zob. AAN, ARPL, 969, Pismo do Ambasady przez Wiktora Drymmera w zastępstwie Naczelnika Prasowego z dn. 4 III 1930 r., k. 2.

39 Były to przykładowo problemy mniejszości narodowych, obraz polskiej wsi, sytuacja opozycji antysanacyjnej. 
się z wszelakiej maści dziennikarzami. Na przykład, gdy w 1937 roku w podróż po Europie Środkowo-Wschodniej udała się niejaka pani Craig zatrudniona przez socjalistyczny tygodnik „New Statesman and Nation”, uzyskała zgodę na spotkanie z podrzędnym przedstawicielem Ministerstwa Spraw Zagranicznych oraz kilkunastoma opozycjonistami, z Wincentym Witosem, Wojciechem Korfantym i Maciejem Ratajem na czele. Skutkiem podróży był zjadliwy artykuł o charakterze antyrządowym ${ }^{40}$.

$\mathrm{Z}$ problemu dużo lepiej zdawano sobie sprawę w Londynie niż w Warszawie. Zresztą bardzo często ambasada przedstawiała centrali problemy, które na ulicy Wierzbowej lekceważono. Każdorazowo naciskano na $\mathrm{MSZ}^{41}$, aby szczególną troską i opieką obejmować nadzwyczajnych korespondentów, w tym przede wszystkim osoby znane $z$ antypolskiego nastawienia, pracujące dla najbardziej poczytnych i opiniotwórczych gazet ${ }^{42}$.

Było jednak wiele czasopism, które w Warszawie nie akredytowały ani nadzwyczajnych, ani tym bardziej stałych korespondentów. W okresie dwudziestolecia międzywojennego Polska nie była państwem, którym szczególnie interesowano by się na Wyspach. Zmiany w tym zakresie zaszły dopiero pod koniec lat 30., kiedy ciężar wydarzeń europejskich przeniósł się nad Wisłę ${ }^{43}$. Wcześniejszy brak zainteresowania wynikał także z faktu, że w Wielkiej Brytanii popularnością cieszyła się tradycyjna polityka zagraniczna polegająca na angażowaniu się w dominiach i terytoriach zależnych kosztem zainteresowania Europą ${ }^{44}$. W rezultacie spora część koncernów prasowych nie czuła potrzeby utrzymywania swoich własnych korespondentów na terenie Europy Środkowo-Wschodniej. Na pomoc przychodziły wówczas agencje prasowe, z którymi zawierano umowy na dostarczanie informacji. W Europie niemal cały rynek został zdominowany przez dwie spośród nich: pochodzącą z Niemiec Reuters i wywodzącą się z ziemi amerykańskiej Press Association ${ }^{45}$.

Pobocznym źródłem wiadomości, mimo dużych ambicji, były polskie placówki dyplomatyczne działające na terenie Wielkiej Brytanii, w tym przede wszystkim ambasada. Pracownicy odpowiedzialni za kontakty z prasą przedstawiali redakcjom różnego rodzaju materiały propagandowe, które nie cieszyły się niestety zbyt wielkim zainteresowaniem; zasadą było poleganie na informacjach pozyskiwanych z własnych źródeł. Pracownicy londyńskiej placówki starali się więc wpływać na te „własne źródła” i przekazywać informacje bezpośrednio korespondentom, którzy (często przez wzgląd na lenistwo) byli najbardziej podatni na propagandę - niestety

40 AAN, ARPL, 729, korespondencja Tomaszewskiego z Kruszyńskim, [b.d.], s. 75.

41 Często robił to osobiście ambasador Edward Raczyński.

42 Przykładem może być wizyta p. Charleston z sierpnia 1930 r., która otrzymała zlecenie od „Daily Express" na serię artykułów o Polsce, v. AAN, ARPL, 696, Pismo Charge d'Affaires Jana Wszelakiego do P VI MSZ z sierpnia 1930 r., s. 92.

43 Możemy wtedy zauważyć radykalny wzrost liczby artykułów prasowych poruszających sprawy polskie.

44 M. Łukasik-Duszyńska, Brytyjskie poselstwo donosi..., Warszawa 2008, s. 125, M. Kamiński, M. Zacharias, Polityka zagraniczna II Rzeczpospolitej 1918-1939, Warszawa 1987, s. 99; D. Jeziorny, Dyplomacja brytyjska wobec koncepcji paktu wschodniego (1933-1935). Analizy, projekty, działania, Łódź 2011, s. 44.

45 J. Silberstein-Loeb, op. cit., s. 150-151. 
nie tylko propolską, ale także antypolską ${ }^{46}$. Dlatego przekazywane materiały, jeśli miały jakieś zastosowanie, to nie w formie bezpośredniego przedruku, a bardziej jako materiały informacyjne dla dziennikarzy ${ }^{47}$. Zwłaszcza od wiosny 1939 roku, kiedy regularnie zaczęto prosić Ambasadę RP w Londynie o udostępnienie materiałów na temat Polski.

\section{KONTAKTY Z REDAKCJAMI POSZCZEGÓLNYCH GAZET}

Efekty przedstawionych powyżej mechanizmów działania nie zawsze były zadowalające dla strony polskiej przede wszystkim dlatego, że na kluczowe elementy kształtujące treści w prasie brytyjskiej dyplomacja polska nie miała wpływu. W żaden sposób nie można było zmienić proweniencji poszczególnych gazet i poglądów osób mających największy wpływ na zamieszczane informacje. Niezależnie od tego, czy osobami decyzyjnymi byli właściciele czy redaktorzy, niemal zawsze byli zupełnie obojętni na polskie życzenia. Polskim dyplomatom udawało się jedynie zdobywać przychylność mniej wpływowych. Jak widziano więc Polskę z perspektywy redakcji najważniejszych brytyjskich gazet?

\section{„The Times"}

„The Times” to nie tylko najstarszy, ale także najbardziej opiniotwórczy dziennik, jaki kiedykolwiek był wydawany na terenie Wielkiej Brytanii. Jedna z niewielu gazet, które walczyły w okresie międzywojennym o zachowanie wysokiego poziomu swoich materiałów kosztem niskiego nakładu. Powiązana z kołami rządowymi, trochę nad wyrost oskarżana o wieczne przedstawianie stanowiska prorządowego, wpływająca na koła finansowe skupione wokół londyńskiego City ${ }^{48}$.

Polska dyplomacja świetnie zdawała sobie sprawę, że wyrażane tam opinie są najważniejsze - niekoniecznie najbardziej szkodliwe (nie trafiały bowiem do szerokiego grona odbiorców), ale najważniejsze ze względu na powiązania gazety ze środowiskiem rządowym. Dlatego należy podkreślić fakt, iż przez większą część okresu międzywojennego pozytywnie oceniano nastawienie „The Timesa” do Polski. Dużo częściej chwalono się przyjaznymi niż wrogimi relacjami z redakcją gazety ${ }^{49}$ oraz w porównaniu z resztą rynku prasowego - relatywnie dużym odsetkiem rzeczowych artykułów na temat Polski. Zawdzięczaliśmy to między innymi przychylności korespondentów stacjonujących w Warszawie. Z przełomu lat 20. i 30. XX wieku znamy

6 AAN, MSZ, 7807, k. 62-63.

47 AAN, MSZ, 8049, k. 124-125.

48 AAN, ARPL, 941, Raport polityczny nr 20/31 z 27 VIII 1931 r., k. 70-71; I. Mc Donald, op. cit., s. 19.

49 AAN, ARPL, 962, Pismo chargé d'affaires do ministra spraw zagranicznych z 27 IV 1927 r., k. 22. 
dwa nazwiska - niejakiego Barkera oraz Gilberta Redferna - obaj byli przedstawiani w wewnętrznych dokumentach MSZ jako rzetelni, obiektywni i profesjonalni dziennikarze i podejmowano starania, aby jak najdłużej pełnili swoje funkcje ${ }^{50}$.

Londyńska ambasada utrzymywała stały kontakt z dziennikarzami pracującymi w dziale zagranicznym „The Timesa”. Najlepiej układały się relacje z Vladimirem Poliakoffem znanym w polskim środowisku pod pseudonimem Augura, który ma na swoim koncie spory dorobek propolskich artykułów i broszur, jak choćby wydanego w 1933 roku The „Polish Corridor”: The Facts mającego podważyć mit odwiecznych niemieckich praw do polskiego Pomorza ${ }^{51}$.

Ambasada miała gorsze relacje z kierownikiem działu zagranicznego, Leo Kennedym, który podobnie jak redaktor naczelny Geoffrey Dawson był jawnym zwolennikiem polityki proniemieckiej ${ }^{52}$. Pozytywny stosunek do Niemiec nie przekładał się na szczęście na ilość niewygodnych dla Polski treści, zwłaszcza dotyczących tematów popularnych w prasie masowej - nieprzestrzegania praworządności oraz sposobu traktowania mniejszości narodowych. Redakcja „The Timesa” wychodziła z założenia, bardzo korzystnego dla Warszawy, że nie należy poprzez wydawane artykuły wpływać na sprawy krajowe, nawet względem najbardziej kontrowersyjnych wydarzeń. Jedynie opisywano, a nie oceniano ${ }^{53}$.

\section{„Manchester Guardian”}

„Manchester Guardian” to kolejny organ należący do wąskiej grupy nazywanej prasą elitarną. Jako pismo niezależne od sfer rządowych cieszył się popularnością wśród zwolenników partii opozycyjnych. W podejściu do kwestii zagranicznych uchodził za życzliwy względem Niemiec, przez co w polskiej ambasadzie był uznawany za „organ interesów niemieckich" ${ }^{54}$. Charakteryzował się bardzo liberalnymi poglądami, co nie korespondowało $\mathrm{z}$ łamaniem w II RP zasady państwa prawa oraz dyskryminacją mniejszości narodowych ${ }^{55}$. Nic więc dziwnego, że w materiałach archiwalnych z lat 30 . negatywnie opisywano ciężkie relacje z redakcją i dziennikarzami „Guardiana”.

Największe problemy sprawiały polskim dyplomatom artykuły poruszające problem dyskryminacji mniejszości narodowych, w tym przede wszystkim żydowskiej

50 AAN, ARPL, 969, Pismo Naczelnika Wydziału Prasowego MSZ do Ambasady RP w Londynie z 17 III 1930 r., s. 2; AAN, MSZ, 7809, Spis korespondentów zagranicznych zarejestrowanych w P VI MSZ, k. 2-5.

51 AAN, ARPL, 941, Raport polityczno-prasowy Konstantego Skirmunta ze I 1933 r., [b.p.].

52 Ibidem; The Times and Appeasement: TheJjournals of A.L. Kennedy, 1932-1939, ed. G. Marte1, Cambridge 2000.

53 AAN, ARPL, 941, Pismo ambasadora Skirmunta do ministerstwa z 5 XII 1929 r., k. 19.

54 K. Kania, Wielka Brytania 1918-1939 w świetle polskich dokumentów dyplomatycznych, Toruń 2007, s. 226-228.

55 Inne liberalne gazety, w tym przede wszystkim „Observer”, miały wzorować się na „Guardianie”. 
oraz ukraińskiej ${ }^{56}$. Jednym z bardziej krytycznych momentów miał miejsce 1931 roku, kiedy przez blisko dwa tygodnie nie znikały z dziennika artykuły na temat tak zwanej pacyfikacji Małopolski Wschodniej, która zdaniem Konstantego Skirmunta przyniosła utratę wszelkiej sympatii brytyjskiej opinii publicznej ${ }^{57}$. W tej i innych podobnych sytuacjach stosowano nadzwyczajne środki - wydawano specjalne biuletyny, które przesyłano do redakcji wszystkich najważniejszych gazet, ale także do opiniotwórczych instytucji oraz osób powiązanych ze światem prasy i polityki ${ }^{58}$. Szczególną rolę odgrywał wówczas Franciszek Bauer-Czarnomski pełniący funkcję attaché prasowego ${ }^{59}$.

Liczba nieprzychylnych Polsce artykułów publikowanych w „Manchester Guardian" była wypadkową nie tylko charakteru gazety, ale również braku szczęścia do korespondentów. Na przełomie lat 20. i 30. dziennik nie oddelegował do Warszawy nikogo, a odpowiedzialnym za tematykę polską był korespondent berliński, Frederick Voigt. Ambasada RP w Londynie systematycznie narzekała na niego, zwłaszcza po 1931 roku, kiedy ponadmiesięczny urlop Voigta skorelował się z osłabieniem nagonki na Polskę ${ }^{60}$. Co ciekawe, gdy w drugiej połowie lat 30 . Voigh został awansowany do roli sprawozdawcy dyplomatycznego i przeniesiony do Londynu, ambasada zaczęła się chwalić poprawnymi relacjami z dziennikarzem, który „znalazł zrozumienie" dla polskiej polityki zagranicznej ${ }^{61}$. Problem całkowicie nie zniknął, bo wraz z przeniesieniem Voigta zatrudniono w Warszawie stałego korespondenta, którym został Żyd Joel Cang, określany w wewnętrznych dokumentach jako „inteligentny, ale powierzchowny”62. Za jego „kadencji” nie obyło się bez niezręcznych dla Polski artykułów, zwłaszcza dotyczących złego traktowania mniejszości żydowskiej $^{63}$. Pod koniec 1937 roku podjęto nawet starania zmierzające do usunięcia Canga z pełnionego stanowiska ${ }^{64}$.

Zdaniem Krzysztofa Kani nadużyciem byłoby stwierdzenie, że przedstawione wyżej przykłady świadczą o negatywnym podejściu do Polski ${ }^{65}$. „Manchester Guardian" był przede wszystkim dziennikiem liberalnym. Nie mógł więc pochwalać funkcjonującego nad Wisłą autorytaryzmu, a w sposób szczególny musiał reagować na dyskryminację mniejszości narodowych. Obrazowo pisał o tym w swoich wspomnieniach Konstanty Skirmunt:

56 AAN, ARPL, 941, Korespondencja Kruszwickiego z Tomaszewskim, k. 82.

57 Polskie dokumenty dyplomatyczne 1931, op. cit., s. 4-6.

58 K. Skirmunt, op. cit., s. 174.

59 AAN, ARPL, 946, Pismo sekretarza Czarnomskiego do redaktora naczelnego „Baltische Presse" z 2 XII 1930 r., k. 87; IPMS, ARPL, A. 12 327/3, Raport polityczny nr 12/8 z VI 1937 r., k. 10.

60 AAN, ARPL, 941, Raport polityczny nr 2/31 z 29 I 1931 r., s. 27-31.

${ }_{61}$ IPMS, ARPL, A.12.327/3, Pismo Jana Tomaszewskiego do Wydziału Prasowego MSZ, k. 19.

62 Pisał również dla „Daily News Chronicle” oraz „Star”.

${ }_{63}$ AAN, MSZ, 7809, Spis korespondentów zagranicznych zarejestrowanych w P VI MSZ, k. 2.

${ }^{64}$ IPMS, ARPL, A12.327/5, Pismo ambasadora Raczyńskiego do Wydziału Prasowego MSZ, k. 11 12.

${ }_{65}$ K. Kania, Wielka Brytania w świetle..., s. 226-228. 
[...] niektóre wiadomości, przychodzące z Polski w owym czasie, były takie, że obrona ujawnionej w nich akcji naszego rządu była niemożliwą. Takimi były wieści o procesie [brzeskim] [...]. Takiej działalności rządowej nikt nie zdołał był obronić wobec angielskiej opinii publicznej i najlepsze, czego można było życzyć, to, by takie wypadki przeszły niepostrzeżenie ${ }^{66}$.

„Guardiana” broni również fakt, że w latach 30. gazeta wyrażała sprzeciw wobec roszczeń Republiki Weimarskiej wobec Polski, wzmagających się w okresie rządów Franza von Papena (1932) i Kurta von Schleichera (1932-1933). W ambasadzie zwracano uwagę, że była to jedna z niewielu gazet poruszających ten problem ${ }^{67}$.

Sprzeciw wobec roszczeń niemieckich nałożył się w czasie z tragiczną śmiercią redaktora naczelnego, C.P. (Charlesa Prestwicha) Scotta, który do 1932 roku niepodzielnie kreował linię polityczną gazety. Nie ogłoszono od razu wiosny w relacjach z „Gaurdianem”, podjęto natomiast starania zmierzające do zdobycia stałych przyjaznych kontaktów wewnątrz redakcji ${ }^{68}$. Było to o tyle łatwiejsze, że zachodzące w Niemczech zmiany polityczne przyniosły kres proniemieckich sympatii dziennika dostrzegającego coraz większe zagrożenie dla Polski ${ }^{69}$. Jedynie problem dyskryminacji mniejszości narodowych, przede wszystkim żydowskiej, nie zniknął aż do $1939 \mathrm{roku}^{70}$.

\section{„Daily Telegraph”}

„Daily Telegraph” to ostatni z dużych dzienników należących do elitarnego nurtu, określany przez pracowników polskiej ambasady jako gazeta skierowana przede wszystkim do zamożnego mieszczaństwa. Na relacje z „Daily Telegraph” raczej nie narzekano. Od początku lat 30 . ambasada i wydział prasowy MSZ utrzymywały stały kontakt $\mathrm{z}$ redaktorem zagranicznym Charlesem Woodsem ${ }^{71}$. Nie ma informacji odnoszących się do drugiej połowy lat 30., kolejny raz „Daily Telegraph” pojawia się dopiero w 1940 roku, kiedy to w korespondencji z ambasadorem Edwardem Raczyńskim właściciel gazety, William Berry lord Camrose, obiecywał przychylić się do prośby o korzystanie z materiałów przygotowywanych przez związanych z polską ambasadą dziennikarzy ${ }^{72}$. Warszawskim korespondentem „Daily Telegraph” był wspominany wyżej Gilbert Redfern, o którym polska ambasada miała jak najlepsze zdanie. Niestety w pisaniu artykułów do „Daily Telegraph” wyręczała go czasami żona Czeszka, co zazwyczaj kończyło się zjadliwymi tekstami ${ }^{73}$. Innych problemów nie było.

66 K. Skirmunt, op. cit., s. 175.

67 AAN, ARPL, 941, Raport polityczny nr 27/32 z 20 X 1932 r., k. 124.

68 AAN, ARPL, 941, Raport polityczny nr 15/32 z 23 VI 1932 r., k. 101-102.

69 IPMS, ARPL, P12.327/5, Korespondencja ambasadora Edwarda Raczyńskiego z Frederickiem Voigtem, k. 24-27.

70 AAN, ARPL, 941, Raport polityczno-prasowy Konstantego Skirmunta ze I 1933 r., [b.p.].

71 Ibidem.

72 IPMS, A.12.327/2, k. 2.

73 AAN, MSZ, 7764, k. 9. 


\section{"Daily Mail” i “Daily Express"}

„Daily Mail” i „Daily Express” to dzienniki należące do grona prasy masowej. Nieodłączną ich cechą było lekceważenie spraw zagranicznych i skupianie się na kwestiach wewnętrznych. Nic więc dziwnego, że o Polsce za bardzo się nie rozpisywano. Jeśli już zdarzył się jakiś artykuł, zwykle był powiązany ze sprawami wewnętrznymi i okraszony nutką sensacji. Nie na darmo Winston Churchill mawiał wówczas, że „dawne gazety pisały o bitwie pod Trafalgarem tak, jakby relacjonowały wypadek uliczny, [...] «Daily Mail» pisze o wypadku ulicznym, jakby to była bitwa pod Trafalgarem"74. Na przykład w kwietniu 1931 roku ukazał się w gazecie artykuł, w którym spekulowano na temat tajnej wizyty Józefa Piłsudskiego w Londynie, której celem było omówienie zagrożenia sowieckiego ${ }^{75}$.

Redaktorów naczelnych „Daily Mail” zmieniał w latach 20. i 30. kilkakrotnie, ale żaden z nich nie zajmował się tematami wykraczającymi poza sprawy wewnątrzpaństwowe, pozostawiając dział zagraniczny zastępcom. Zresztą to nie oni, a właściciel, lord Rothermere, jednoosobowo kierował gazetą i kształtował jej profil ${ }^{76}$. „Daily Mail" miał swoich korespondentów w Warszawie, znamy nazwiska aż czterech spośród nich: Feliks Rzewuski, Mieczysław Nowiński, a także nieznani z imienia: Kleczkowski oraz Coeg. Wszyscy legitymowali się obywatelstwem polskim i najprawdopodobniej jedynie dorabiali, pracując dla dziennika. Rzewuskiego chwalono przy ulicy Wierzbowej. W połowie lat 30 . podjęto nawet starania zmierzające do przywrócenia go do porzuconej funkcji korespondenta zagranicznego „Daily Mail"'77. O reszcie wiemy niewiele. Z Kleczkowskiego najprawdopodobniej MSZ nie był zadowolony, skoro chciał go zastąpić właśnie Rzewuskim. Mieczysława Nowińskiego (pracującego również dla „Daily Express”) opisywano jako „inteligentnego, ale plotkarza, którego trzeba się wystrzegać"78.

„Daily Express” sprawami Europy nie interesował się w ogóle, a jej częścią wschodnią w szczególności, nawet jak na standardy prasy masowej. Było to bezpośrednio powiązane z poglądami właściciela, Maxa Aitkena lorda Beaverbrooka, który niezmiennie kierował gazetą. Arthur Christiansen, redaktor naczelny w latach 30. XX wieku, pisał w swojej autobiografii, że Beaverbrook zalewał go telefonicznie sugestiami dotyczącymi „głównych artykułów, konkretnych pomysłów, treści informacji, plotkarskich ustępów" - sugestiami, których redaktor nie mógł nie uwzględnić $^{79}$. Beaverbrook był zwolennikiem ścisłej współpracy między Wielką Brytanią a jej dominiami i temu poświęcał większość rubryk dotyczących spraw zagranicznych. Popierał także izolacjonistyczną politykę na scenie europejskiej ${ }^{80}$. Polska służba

\footnotetext{
14 A. Paczkowski, op. cit., s. 84.

AAN, ARPL, 941, Raport polityczny nr 6/31 z 9 IV 1931 r., k. 45.

${ }^{6}$ AAN, ARPL, 941, Raport polityczno-prasowy Konstantego Skirmunta ze I 1933 r., [b.p.].

7 AAN, MSZ, 7809, Spis korespondentów zagranicznych zarejestrowanych w P VI MSZ, s. 2-5.

78 Ibidem.

79 G. Boyce, J. Curran, op. cit., s. 141.

80 AAN, ARPL, 941, Raport polityczno-prasowy Konstantego Skirmunta ze I 1933 r. [b.p.]; A. Robert, Voice of Britain, the Inside Story of the Daily Express, Cambridge 1983, s. 67.
} 
dyplomatyczna nad wyraz czujnie podchodziła do jego osoby, skoro samodzielnie kreował politykę dziennika o kilkumilionowym nakładzie ${ }^{81}$. Na kartach pamiętnika W sojuszniczym Londynie Raczyński pisał o Beaverbrooku, że był „championem brytyjskiego imperializmu z małpią wprost złośliwością czepiającego się tej lub innej ofiary, z upodobaniem szkodzącego Polsce" ${ }^{" 82}$. Opinia ambasadora nie była raczej bezpodstawna, skoro na przykład we wrześniu 1932 roku ukazał się na łamach „Daily Express” artykuł autorstwa samego Beaverbrooka, w którym wyraził opinię, że utworzenie polskiego korytarza było niesprawiedliwym posunięciem. Postanowił uzmysłowić to czytelnikom, tworząc wizję funkcjonowania podobnego korytarza pomiędzy Anglią a Szkocją ${ }^{83}$. Co ciekawe, na identyczny przykład powoływała się kilka lat później propaganda niemiecka ${ }^{84}$.

\section{„Daily Herald”}

Omawiając stosunek do Polski najważniejszych brytyjskich gazet, nie sposób pominąć „Daily Herald” ze względu na imponujący nakład (ponad $2 \mathrm{mln}$ ) oraz specyficzny charakter gazety, której właściwie nie można zaliczać do prasy masowej - była przede wszystkim gazetą partyjną związaną z ruchem socjalistycznym kopiującym poglądy Partii Pracy oraz związków zawodowych ${ }^{85}$. Artykułów dotyczących spraw zagranicznych było raczej niewiele, a dotyczące Polski były zasadniczo przychylne, zwłaszcza jeśli poruszały problem relacji polsko-niemieckich oraz statusu Wolnego Miasta Gdańska. „Daily Herald” jako jeden z pierwszych ostrzegał brytyjską opinię publiczną przed narastającymi aspiracjami niemieckimi ${ }^{86}$. Jedynym momentem, kiedy o Polsce pisano raczej źle, był listopad 1937 roku, kiedy to pracownicy londyńskiej ambasady próbowali kojarzyć z nasilającą się propagandą sowiecką widoczną w całej prasie brytyjskiej ${ }^{87}$.

Co ciekawe, gazeta mimo niewielkiego zainteresowania sprawami zewnętrznymi miała w Polsce korespondenta, którym był Polak o żydowskich korzeniach Jerzy Szapiro. Został określony w polskich dokumentach dyplomatycznych jako osoba ciesząca się dobrą opinią wśród kolegów po fachu, co zawdzięczać miał profesjonalnemu podejściu do pracy. Niestety nie można było liczyć na jego lojalność względem władz polskich, co przede wszystkim wynikało z żydowskiego pochodzenia.

81 Zainteresowania jego osobą nie można porównać do żadnego innego magnata prasowego.

82 K. Kania, Edward Bernard Raczyński 1891-1993 dyplomata i polityk, Warszawa 2014, s. 125; por. E. Raczyński, W sojuszniczym Londynie. Dziennik ambasadora Edwarda Raczyńskiego 19391945, Londyn 1974, s. 11.

83 AAN, ARPL, 941, Raport polityczny nr 25/32 z 16 IX 1932 r., k. 116.

84 W. Holmes, Wink to Hitler, „Daily Worker”, 22 VIII 1939 r., s. 2.

${ }_{85}$ G. Boyce, J. Curran, op. cit., s. 131.

86 AAN, MSZ, ARPL, 941, Raport polityczny nr 20/32 z 15 VIII 1932 r., k. 111.

87 AAN, ARPL, 696, Raport polityczny nr 24/2 z 24 XI 1937 r., k. 99-101. 
Przedstawione badania mają za zadanie pokazać, jakie były zasady gry w relacjach polskiej służby dyplomatycznej z najważniejszymi brytyjskimi dziennikami w okresie dwudziestolecia międzywojennego oraz jak pod względem technicznym wyglądało pozyskiwanie informacji na temat Polski. Strona polska miała bardzo słabą pozycję startową, co wynikało z kilku czynników, przede wszystkim z marginalnej roli II Rzeczpospolitej w polityce Wielkiej Brytanii, niewielkich nakładów finansowych na ten aspekt działalności oraz z posiadania licznych wrogów działających na niekorzyść Warszawy. Sytuacji nie poprawiał także problem dyskryminacji mniejszości narodowych oraz nieprzestrzegania zasad praworządności. Mimo to podejmowano liczne starania, których celem była poprawa wizerunku Polski w oczach brytyjskiej opinii publicznej.

Codzienną tytaniczną pracę w tym zakresie wykonywali pracownicy Poselstwa, a później Ambasady RP w Londynie, którzy spisywali i przekazywali do Ministerstwa raporty, przygotowywali sprawozdania i wnioski dotyczące proponowanych reform, bezpośrednio naciskali na poszczególne redakcje po nieprzychylnych dla Polski artykułach. Ich praca przynosiła drobne, wymierne korzyści. Kluczem do każdego sukcesu było zyskanie sympatii w środowisku dziennikarskim, którego nie dało się przekupić.

Żadne działania informacyjno-propagandowe nie mogły przynieść ani rewolucyjnych zmian $\mathrm{w}$ postrzeganiu Polski, ani radykalnego wzrostu zainteresowania państwem znad Wisły. Zauważalne zmiany nastąpiły w 1939 roku, choć nie były one zasługą polskich dyplomatów, a wypadkową wydarzeń na europejskiej scenie politycznej. Dnia 15 marca 1939 roku Hitler wkroczył do Pragi, łamiąc tym samym postanowienia układu monachijskiego, co było szokiem dla wszystkich - polityków, społeczeństwa, dziennikarzy ${ }^{88}$. Odpowiedzią Chamberlaina na ten krok było wycofanie się z polityki appeasement i ogłoszenie pod koniec marca gwarancji niepodległości Polski ${ }^{89}$. Bezpośrednim skutkiem przewektorowania polityki zagranicznej Wielkiej Brytanii i pozyskania nowego sojusznika na Wschodzie był spektakularny wzrost zainteresowania społeczeństwa brytyjskiego Polską, co widać na łamach ówczesnej prasy $^{90}$. Z dnia na dzień o Polsce zaczęto pisać dużo i niemal wyłącznie dobrze. Jako że brytyjskie społeczeństwo, zwłaszcza jego mniej wykształcona część sięgająca po prasę popularną, wiedziała naprawdę niewiele o II RP, zaczęły pojawiać się w prasie dość infantylne informacje o miejscu położenia Polski, jej historii czy mentalności społeczeństwa, ale także o potędze polskiego wojska czy słuszności praw

88 J. Thompson, The idea of public opinion in Britain 1870-1914, Cambridge 2000, s. 246.

89 J. Ciechanowski, Wielka Brytania i Polska od Wersalu do Jatty, Pultusk 2008, s. 54; R.P. Żurawski vel Grajewski, Brytyjsko-czechostowackie stosunki dyplomatyczne, październik 1938 - maj 1945, Warszawa 2008, s. 67; A. Prażmowska, Eastern Europe and the Origins of The Second World War, London 2000, s. 148.

90 K. Kania, Polska w przekazie informacyjnym Wielkiej Brytanii (październik 1938 - październik 1939) [w:] Kampania polska 1939. Polityka-społeczeństwo-kultura, t. 2, Warszawa 2015, s. 463-465. 
do Pomorza nienazywanego już korytarzem ${ }^{91}$. Po raz kolejny okazało się, że żadne działania informacyjno-propagandowe czy osobiste relacje dyplomatów ze światem dziennikarskim nie będą mieć takiego przełożenia na prasę jak polityka.

\section{BIBLIOGRAFIA}

\section{Źródła archiwalne}

Archiwum Akt Nowych w Warszawie.

Ministerstwo Spraw Zagranicznych.

Ambasada RP w Londynie.

Instytut Polski i Muzeum im. Władysława Sikorskiego w Londynie.

Ambasada RP w Londynie.

\section{Źródła drukowane}

Polskie dokumenty dyplomatyczne 1931, red. M. Wołos, Warszawa 2008.

Raczyński E., W sojuszniczym Londynie. Dziennik ambasadora Edwarda Raczyńskiego 1939-1945, Londyn 1974.

Skirmunt K., Moje wspomnienia 1866-1945, Rzeszów 1997.

The Times and Appeasement: The Journals of A.L. Kennedy, 1932-1939, ed. G. Martel, Cambridge 2000.

\section{Opracowania}

A Journalism Reader, eds. M. Bromley, T. O’Malley, London 1997.

Boyce G., Curran J., Newspaper History from the Seventeenth Century to the Present, London 1978.

Ciechanowski J., Wielka Brytania i Polska od Wersalu do Jałty, Pułtusk 2008.

Griffiths D., A Century of Journalism, 1900-2000, Oxford 2012.

Jeziorny D., Dyplomacja brytyjska wobec koncepcji paktu wschodniego (1933-1935). Analizy, projekty, działania, Łódź 2011.

Kamiński M., Zacharias M., Polityka zagraniczna II Rzeczpospolitej 1918-1939, Warszawa 1987.

Kuta H., Meissner L., Prasa za granicą. Sylwetki 147 wybranych dzienników i czasopism z 39 krajów oraz krótkie charakterystyki 14 agencji prasowych, Kraków 1972.

Łukasik-Duszyńska M., Brytyjskie poselstwo donosi..., Warszawa 2008.

91 IPMS, ARPL, A.12.317/2, Pismo ambasadora Raczyńskiego do Ministerstwa Spraw Zagranicznych z 13 VI 1939 r., s. 1-6. 
Kania K., Edward Bernard Raczyński. Dyplomata i polityk, Warszawa 2014.

Kania K., Polska w przekazie informacyjnym Wielkiej Brytanii (październik 1938 - październik 1939) [w:] Kampania polska 1939. Polityka, społeczeństwo, kultura, T. 2: Polityka i spoleczeństwo. Imponderabilia, pamięć, kultura, red. M.P. Deszczyński, T. Pawłowski, Warszawa 2015.

Kania K., Wielka Brytania w świetle polskich dokumentów dyplomatycznych, Toruń 2007.

McDonald I., The History of the Times. Vol. 5: Struggles in War and Peace, 1939-1966, London 1984.

Paczkowski A., Czwarta wtadza. Prasa dawniej i dziś, Warszawa 1973.

Pudłocki T., Ambasadorzy idei. Wkład intelektualistów w promowanie pozytywnego wizerunku Polski w Wielkiej Brytanii w latach 1918-1939, Kraków 2015.

Prażmowska A., Eastern Europe and the Origins of the Second World War, London 2000.

Richards H., The Bloody Circus: The Daily Herald and the Left, London 1997.

Robert A., Voice of Britain, the Inside Story of the Daily Express, Cambridge 1983.

Silberstein-Loeb J., The International Distribution of the News: The Associated Press, Press Association and Reuters, 1848-1947, Cambridge 2014.

Słomkowska A., Krótki zarys historii prasy brytyjskiej, Warszawa 1978.

Sobczak J., Propaganda zagraniczna Niemiec Weimarskich wobec Polski, Poznań 1973.

Szczepanik K., Dyplomacja Polski 1918-2000. Struktury organizacyjne, Warszawa 2000.

Thompson J., The Idea of Public Opinion in Britain 1870-1914, Cambridge 2000.

W obliczu wojny. Z prasy polskiej 1939 roku, wybór i oprac. red. miesięcznika „Znak”, Kraków 1984.

Walker M., Power of the Press: The World's Great Newspapers, London 1995.

Williams K., Read All about It!: A history of the British Newspaper, London 2009.

Zięba A., Lobbing dla Ukrainy w Europie międzywojennej. Ukrainskie Biuro Prasowe w Londynie oraz jego konkurenci polityczni (do roku 1932), Kraków 2010.

Żurawski vel Grajewski R.P., Brytyjsko-czechosłowackie stosunki dyplomatyczne, październik 1938 - maj 1945, Warszawa 2008. 